Tropical Journal of Pharmaceutical Research February 2017; 16 (2): 349-356

ISSN: $1596-5996$ (print); 1596-9827 (electronic) (c) Pharmacotherapy Group, Faculty of Pharmacy, University of Benin, Benin City, 300001 Nigeria.

All rights reserved.

Available online at http://www.tjpr.org

Original Research Article

http://dx.doi.org/10.4314/tjpr.v16i2.13

\title{
Genistein attenuates ischemia/reperfusion injury in rat kidneys via enhancement of antioxidant defense mechanisms: Activation of $\mathrm{Nrf-2/HO-1} \mathrm{signaling}$
}

\author{
Shou-Liang Wang ${ }^{1}$, Lian Duan ${ }^{2}$, Wei Li $^{1}$, Gong-Ming Wang ${ }^{1}$ and Meng-Yuan \\ Zhang ${ }^{1 *}$ \\ ${ }^{1}$ Department of Anesthesiology, Shandong Provincial Hospital Affiliated to Shandong University, Jinan 250021, ${ }^{2}$ Department of \\ Ophthalmology, Qianfoshan Hospital, Medical School of Shandong University, Jinan 250014, China \\ *For correspondence: Email: zhangmy1976@gmail.com; Tel/Fax: 0086-531-68776472
}

\begin{abstract}
Purpose: To investigate the protective role of genistein against ischemic reperfusion (I/R) injury in rat kidneys.

Methods: Group I (control, $n=10$ ) consisted of animals that were not operated on while group II (sham, $n=10$ ) were animals surgically operated on, similar to I/R group without renal bilateral ischemia. Group III (genistein, $n=10$ ) consisted of animals administered $10 \mathrm{mg} / \mathrm{kg}$ genistein by oral gavage for 7 consecutive days while group IV $(I / R, n=10)$ animals were subjected to $45 \mathrm{~min}$ of renal bilateral ischemia followed by $24 \mathrm{~h}$ of reperfusion. Group $V$ (genistein+l/R, $n=10$ ) received $10 \mathrm{mg} / \mathrm{kg}$ genistein by oral gavage for 7 consecutive days and then subjected to $45 \mathrm{~min}$ of renal bilateral ischemia followed by $24 \mathrm{~h}$ of reperfusion. Renal function, total oxidant capacity and total antioxidant status in serum were evaluated in the rats. Further, reactive oxygen species generation as well as levels of protein carbonyl, lipid peroxidation, and enzymatic and non-enzymatic antioxidants were determined. Nrf-2 (nuclear factor (erythroid-derived 2)-like 2) and HO-1 (Heme oxygenase-1) expressions were determined by western blot.

Results: Pre-treatment with genistein $(10 \mathrm{mg} / \mathrm{kg})$ significantly $(p<0.001)$ ameliorated I/R induced renal damage by reducing the levels of serum markers. Genistein pre-treatment significantly decreased $(p<$ $0.001) I / R$ injury induced-ROS, lipid peroxides and protein carbonyl content $(p<0.001)$. I/R injury significantly $(p<0.001)$ decreased non-enzymatic and enzymatic antioxidant activities. Genistein pretreatment also prevented renal I/R injury by significantly up-regulating Nrf-2, HO-1 expressions and antioxidant status.
\end{abstract}

Conclusion: Thus, genistein may be therapeutically useful against kidney $I / R$ injury by improving antioxidant defense mechanisms.

Keywords: Oxidative stress, Genistein, Ischemic reperfusion injury, Renal damage, Antioxidant, Nuclear factor (erythroid-derived 2)-like 2, Heme oxygenase-1, Nrf-2, HO-1

Tropical Journal of Pharmaceutical Research is indexed by Science Citation Index (SciSearch), Scopus, International Pharmaceutical Abstract, Chemical Abstracts, Embase, Index Copernicus, EBSCO, African Index Medicus, JournalSeek, Journal Citation Reports/Science Edition, Directory of Open Access Journals (DOAJ), African Journal Online, Bioline International, Open-J-Gate and Pharmacy Abstracts

\section{INTRODUCTION}

Renal ischemia/reperfusion injury (IRI) causes kidney dysfunction with increased mortality rate [1]. Oxygen impairment and subsequent accumulation of waste products initiates tissue damage $[1,2]$. Reperfusion causes increased free radical production ultimately leading to cellular death through apoptosis/necrosis [3]. Oxidative stress and decline in antioxidant balance are 
central regulatory mechanism in the pathogenesis of renal $\mathrm{I} / \mathrm{R}$ injury [4]. Preconditioning offers protective effect against I/R injury and pre-treatment with pharmacological agents might be a possible therapeutic option against renal I/R injury [5].

Genistein, a plant derived isoflavone has potent anti-oxidative property and offers numerous health benefits including cardioprotection, antiinflammatory and anti-cancer effects $[6,7]$. In the present study, we aimed at investigating whether genistein could offer protection against renal ischemic reperfusion injury by regulating oxidative stress and Nrf-2 signaling.

\section{EXPERIMENTAL}

\section{Animals and study design}

All the animals and protocols used in the present study were followed according to National Research Council for Animal Care [8] and approved by the Ethical Committee (no. NR 016/2014) of Shandong Provincial Hospital affiliated to Shandong University, China, prior to the commencement of the study. Fifty Male Wistar rats (age of 8 - 10 weeks) weighing 180 $220 \mathrm{~g}$ housed under standard conditions. The rats were maintained under controlled conditions of $\left(21 \pm 2{ }^{\circ} \mathrm{C}\right)$ and relative humidity (65-70\%) with alternating $12 \mathrm{~h}$ dark and light cycle. The animals were provided with ad libitum standard laboratory diet and water. After acclimatization, animals were divided randomly into 5 groups with ten animals per group. Genistein and all other chemicals used in the study were purchased from Sigma Aldrich (Shanghai, China).

\section{Study design}

Group I (control, $\mathrm{n}=10$ ) consisted of animals that were not operated on while group II (sham, n $=10$ ) were animals surgically operated on, similar to $\mathrm{I} / \mathrm{R}$ group without renal bilateral ischemia. This was followed by midline laparotomy; the kidneys were located and the renal pedicles with artery, vein and nerve supply were subjected to bilateral ischemia for $45 \mathrm{~min}$. Group III (genistein, $n=10$ ) consisted of animals administered $10 \mathrm{mg} / \mathrm{kg}$ genistein by oral gavage for 7 consecutive days while group IV (I/R, $\mathrm{n}=$ 10) animals were subjected to $45 \mathrm{~min}$ of renal bilateral ischemia followed by $24 \mathrm{~h}$ of reperfusion. Group V (genistein+l/R, $\mathrm{n}=10$ ) received $10 \mathrm{mg} / \mathrm{kg}$ genistein by oral gavage for 7 consecutive days and then subjected to $45 \mathrm{~min}$ of renal bilateral ischemia followed by $24 \mathrm{~h}$ of reperfusion. At the end of treatment period, the animals were fasted for $12 \mathrm{~h}$, and anaesthetized with xylazine (10 mg/kg) and ketamine (100 $\mathrm{mg} / \mathrm{kg}$ ). Heating lamp was used to maintain body temperature $(37.5 \stackrel{\circ}{\circ})$. Abdominal region was sterilized with povidine iodine solution and both the kidneys were isolated by midline incision procedure. The abdomen was closed in the sham group alone. In I/R and genistein + I/R administered groups, non-traumatic microvascular clamps were used to occlude renal arteries for $45 \mathrm{~min}$. After $45 \mathrm{~min}$, the clamps were removed blood flow was restored to the kidney and the incision closed.

After $24 \mathrm{~h}$ reperfusion, the animals were anesthetized and blood was collected by cardiac puncture and the separated serum used for serum biomarker analysis. Nephrectomy was performed and the isolated kidney used for biochemical and molecular studies.

\section{Assessment of renal function markers}

Serum urea nitrogen was determined as described previously [9]. To $0.1 \mathrm{ml}$ of serum, 3.3 $\mathrm{ml}$ of double-distilled water, $0.3 \mathrm{ml}$ of $10 \%$ sodium tungstate and $0.3 \mathrm{ml}$ of $0.67 \mathrm{~N}$ sulfuric acid were added. The samples were centrifuged at $4000 \mathrm{rpm}, 15 \mathrm{~min}$ ). To the supernatant, $1 \mathrm{ml}$ of double-distilled water, $0.4 \mathrm{ml}$ of diacetyl monoxime reagent and $0.6 \mathrm{ml}$ of sulfuric acidphosphoric acid mixture were added and in a boiling water bath for $30 \mathrm{~min}$. The samples were cooled to room temperature and the absorbance was read at $480 \mathrm{~nm}$ in a Shimadzu UV - 1700 spectrophotometer. Creatinine was estimated using the method described previously [10]. To $1.0 \mathrm{ml}$ of serum $8.0 \mathrm{ml}$ of double-distilled water, $0.5 \mathrm{ml}$ of $2 / 3 \mathrm{~N}$ sulfuric acid and $0.5 \mathrm{ml}$ of $10 \%$ sodium tungstate were added and centrifuged (4000 rpm, $15 \mathrm{~min}$ ). To $5.0 \mathrm{ml}$ of the clear supernatant, $1.5 \mathrm{ml}$ of saturated picric acid and $1.5 \mathrm{ml}$ of $0.75 \mathrm{~N}$ sodium hydroxide were added and incubated for 15 mins. The absorbance was read at $460 \mathrm{~nm}$ in Shimadzu UV - 1700 spectrophotometer.

\section{Evaluation of serum total antioxidant capacity (TAC) and total oxidant status (TOS)}

Serum TAC levels were determined using a novel automated measurement method [11]. The hydroxyl radical produced through free radical reactions is directly proportional to the antioxidant levels in the serum. The results are expressed as $\mu \mathrm{mol}$ Trolox Eq/L. Serum TOS values were determined as described previously [12]. The colour intensity is directly proportional to the oxidant molecules in the serum. The assay is calibrated with hydrogen peroxide $\left(\mathrm{H}_{2} \mathrm{O}_{2}\right)$ and the results are expressed in terms of micromolar 
hydrogen peroxide equivalent per litre $(\mu \mathrm{mol}$ $\left.\mathrm{H}_{2} \mathrm{O}_{2} \mathrm{Eq} / \mathrm{L}\right)$.

\section{Measurement of oxidative stress and antioxidant status}

The tissues were homogenized using ice-cold 50 $\mathrm{mM}$ Tris- $\mathrm{HCl}$ buffer ( $\mathrm{pH}$ 7.4) and centrifuged at 3,000 rpm for $15 \mathrm{~min}$ (KUBOTA, KR-20000T). The supernatant was aliquoted and stored at - 20 ${ }^{\circ} \mathrm{C}$ for further analysis. Protein estimation was performed as described previously [13].

\section{Determination of reactive oxygen species}

The levels ROS was determined as described previously [14]. To the kidney homogenate added $5 \mathrm{mM}$ potassium phosphate buffer $(\mathrm{pH}$ 7.4) and 2',7' -dichlorofluorescein diacetate DCFDA $(10 \mu \mathrm{M})$, incubated at $37^{\circ} \mathrm{C}$ for $15 \mathrm{~min}$ followed by centrifugation (10,000 rpm, $10 \mathrm{~min}$ ). The pellet suspended in phosphate buffered saline was incubated for $60 \mathrm{~min}$ at $37^{\circ} \mathrm{C}$. Fluorescence intensity was measured at excitation (485 nm) and emission (528 nm) in a spectrofluorometer (Thermo Scientific, Waltham, MA). The results were expressed in percentage ROS generation was computed relative to control value and expressed as percentage.

\section{Determination of tissue protein carbonyl content (PCC)}

Tissue protein carbonyl content was determined as described previously [15]. The samples were treated with $10 \mathrm{mM}$ DNPH in $2 \mathrm{M} \mathrm{HCl}$ and incubated at room temperature for $1 \mathrm{hr}$ (shaking). The hydrazone derivatives were precipitated with $20 \%$ trichloroacetic acid and then was treated with ethanol/ethyl acetate, 1:1 to remove excess DNPH, and then re-precipitated with $10 \%$ trichloroacetic acid. The pellet was dissolved in $6 \mathrm{M}$ guanidine hydrochloride. The absorbance was measured at $370 \mathrm{~nm}$ (Shimadzu UV - 1700 spectrophotometer). The results were calculated as nmole of DNPH incorporated/mg of protein. The results were expressed as nanomoles of carbonyl/mg of protein.

\section{Lipid peroxidation assay}

Thiobarbituric acid reactive species (TBARS) content was determined as described previously [16]. To the $0.1 \mathrm{ml}$ homogenate added, $200 \mu \mathrm{l}$ of butylated hydroxytoluene (BHT) in methanol, 200 $\mu \mathrm{l} 1 \mathrm{M}$ phosphoric acid and $350 \mu \mathrm{l}$ of TBA (Thiobarbituric acid) solution. The tubes were mixed vigorously and incubated for $60 \mathrm{~min}$ at 60 ${ }^{\circ} \mathrm{C}$. The mixture was centrifuged at $10,000 \mathrm{~g}$ for 10 mins. The supernatant was read at $532 \mathrm{~nm}$.
The amount of TBARS formed was calculated using extinction coefficient, $E=1.56 \times 10^{5}$ ). The results are expressed as thiobarbituric acid reactants formed $/ \mathrm{mg}$ of protein.

\section{Evaluation of antioxidant enzyme activities}

\section{Glutathione (GSH)}

The samples were precipitated with using TCA and centrifuged at $6000 \mathrm{~g}$ for $15 \mathrm{mins}$. The supernatant was treated with DTNB (5,5'dithiobis- (2-nitrobenzoic acid), where the -SH group of GSH reacts with DTNB and the yellow coloured product was measured at $405 \mathrm{~nm}$. The GSH content was determined using the standard GSH concentration. The results were expressed as Units/mg of protein. $1 \mathrm{U}=$ nmoles of $\mathrm{GSH} / \mathrm{mg}$ of protein.

\section{Superoxide dismutase (SOD) activity}

The SOD activity was determined as described [17]. To $0.1 \mathrm{ml}$ of homogenate, added $50 \mathrm{mM}$ Tris-cacodylic acid buffer ( $\mathrm{pH} 8.2)$, and pyrogallol solution $(0.2 \mathrm{mM})$ and EDTA $(1 \mathrm{mM})$. Followed by which the reading was measured for 3 mins (30 sec interval). The method measures the auto-oxidation of pyrogallol and 1 unit = the amount of enzyme required to inhibit pyrogallol auto-oxidation by $50 \%$.

\section{Glutathione-S-Transferase (GST) activity}

The reaction mixture contained $0.1 \mathrm{ml}$ of homogenate in $0.1 \mathrm{M}$ phosphate buffer $(\mathrm{pH} \mathrm{6.5)}$, $1 \mathrm{mM}$ 1-chloro-2, 4-dinitrobenzene (CDNB), and $1 \mathrm{mM} \mathrm{GSH}$ in a final volume of $3 \mathrm{ml}$. Followed by which the reading was measured for 3 mins (30 sec interval). The enzyme activity was determined using extinction coefficient of GSCDNB, $E_{340}=0.0096 \mu \mathrm{M}^{-1} \mathrm{~cm}^{-1}$ and expressed as Units $/ \mathrm{mg}$ of protein. $1 \mathrm{U}=$ nmoles of CDNB conjugated $/ \mathrm{min} / \mathrm{mg}$ protein [18].

\section{Glutathione peroxidase (GPx) activity}

GPx was performed as described by [19]. To 0.1 $\mathrm{ml}$ of homogenate in $50 \mathrm{mM}$ phosphate buffer $\mathrm{pH}$ 7.0 , added $0.5 \mathrm{ml}$ sodium azide $(0.1 \mathrm{mM}), 1 \mathrm{ml}$ glutathione $(0.5 \mathrm{mM}), 1.2 \mathrm{ml}$ hydrogen peroxide $(1 \mathrm{mM})$. To the above reaction mixture added $0.5 \mathrm{ml}$ of $10 \%$ TCA and incubated for 5 mins at $37^{\circ} \mathrm{C}$ and centrifuged at $5000 \mathrm{rpm}$ for 15 mins. To the supernatant $(0.1 \mathrm{ml})$, added $5,5^{\prime}$-Dithio-bis (2-nitrobenzoic acid) (DTNB) and the read at 412 $\mathrm{nm}$. $1 \mathrm{U}=1 \mu$ mole GSH to GSSG in the presence of $\mathrm{H}_{2} \mathrm{O}_{2} / \mathrm{min}$. The enzyme activity was expressed as units/mg protein. 


\section{Catalase (CAT) activity}

The activity was determined according to the method described by [20]. To $0.1 \mathrm{ml}$ of tissue homogenate added, $50 \mathrm{mM}$, phosphate buffer, $\mathrm{pH}$ 7.0. $1.0 \mathrm{ml}$ of $10 \mathrm{mM} \mathrm{H}_{2} \mathrm{O}_{2}$ was added and the reading was measured for 3 mins (30 sec interval) at $240 \mathrm{~nm}$. The enzyme activity was determined using extinction coefficient of $\mathrm{H}_{2} \mathrm{O}_{2}$ $\left(E_{240}=43.6 \mathrm{M}^{-1} \mathrm{~cm}^{-1}\right)$ and expressed as Units $/ \mathrm{mg}$ of protein. $1 \mathrm{U}=\mu \mathrm{M}$ of $\mathrm{H}_{2} \mathrm{O}_{2}$ utilized/min/mg protein.

\section{Western blot analysis}

The tissues were homogenized and nuclear and cytoplasmic extract were isolated from Cellytic Nuclear Extraction kit. The protein isolated was loaded in $12 \%$ SDS-PAGE gels and the separated proteins were transferred into NC (nitrocellulose) membrane. The membrane was incubated with primary and secondary antibodies for Nrf-2 and HO-1 proteins and developed with super signal ECL kit. The bands were developed and analyzed using Image $\mathrm{J}$ software.

\section{Statistical analysis}

The data were analyzed using one-way analysis of variance (ANOVA) followed by Tukey's multiple comparison test using SPSS version 10.0). The level of significance was set variously at $p<0.05, p<0.01$ and $p<0.001$.

\section{RESULTS}

Renal I/R injury caused significant increase $(p<$ 0.001 ) in serum kidney markers urea and creatinine when compared to control rats. Sham rats and Genistein treated rats showed nonsignificant difference in serum biomarkers when compared to control group. Treatment with Genistein followed by I/R restored the kidney function by reducing renal markers $(p<0.001)$ compared to $\mathrm{l} / \mathrm{R}$ rats (Fig1A and $1 \mathrm{~B})$. $\mathrm{I} / \mathrm{R}$ rats showed significant increase $(p<0.001)$ in TOS levels with concomitant decrease $(p<0.01)$ in TAC levels compared to control group. However, in rats pre-treated with genistein followed by $\mathrm{I} / \mathrm{R}$ injury showed significant decrease $(p<0.001)$ in TOS levels with concomitant increase $(p<0.01)$ in TAC (Table 1).

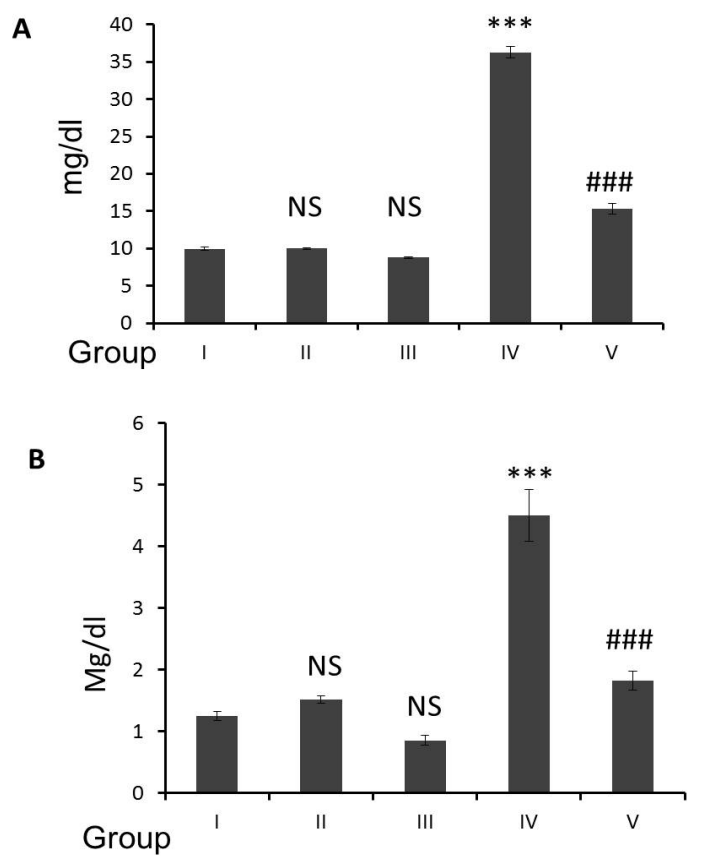

Figure 1: Genistein on renal biomarkers during I/R injury. Serum creatinine $(A)$ and serum urea $(B)$ levels in renal $I / R$ injury rats pre-treated with genistein. Group I (control); Group II (sham): Group III (genistein): Group IV (I/R): Group V (genistein + I/R). Results are given as the mean \pm SEM for 10 rats in each group; ${ }^{* * *} p<0.001$, when compared to control; $\# \#<0.001$, when compared to I/R group

\section{Genistein ameliorates I/R injury}

Rats with $\mathrm{I} / \mathrm{R}$ injury showed a significant increase $(p<0.001)$ in the levels of lipid peroxides (Figure 2 ), protein carbonyl content (Figure 3) and reactive oxygen species (Figure 4) when compared to control rats. These levels were significantly decreased $(p<0.001)$ in rats treated with genistein followed by I/R injury. Rats treated with genistein/sham-operated rats showed nonsignificant levels of oxidative markers when compared to control group.

Table 1: Effect of genistein on total antioxidant capacity (TAC) and total oxidant status (TOS) in ischemic reperfusion injury in rat kidneys

\begin{tabular}{lccccc}
\hline Parameter & Group I & Group II & Group III & Group IV & Group V \\
\hline TAC & $3.12 \pm 0.01$ & $3.15 \pm 0.01^{\mathrm{NS}}$ & $3.67 \pm 0.01^{\mathrm{NS}}$ & $1.17 \pm 0.01^{* * *}$ & $2.98 \pm 0.01^{\# \# \#}$ \\
TOS & $34 \pm 2.0$ & $32 \pm 2.21^{\mathrm{NS}}$ & $34.1 \pm 2.01^{\mathrm{NS}}$ & $47 \pm 2.76^{* *}$ & $32 \pm 2.98^{\# \#}$ \\
\hline
\end{tabular}

Group I (control); Group II (Sham): Group III (Genistein): Group IV (I/R): Group V (genistein + I/R). Results are given as the mean \pm SEM for 10 rats in each group. ${ }^{* * *} p<0.001,{ }^{* *} p<0.01$ when compared to control. $\# \#<0.001,{ }^{\#} p<0.01$ when compared to I/R group. NS, Not Significant when compared to control (One way ANOVA followed by Tukey's multiple comparison). TAC is expressed as $\mu \mathrm{mol}$ Trolox Eq/L; TOS is expressed as $\mu \mathrm{mol} \mathrm{H}_{2} \mathrm{O}_{2} \mathrm{Eq} / \mathrm{L}$ 


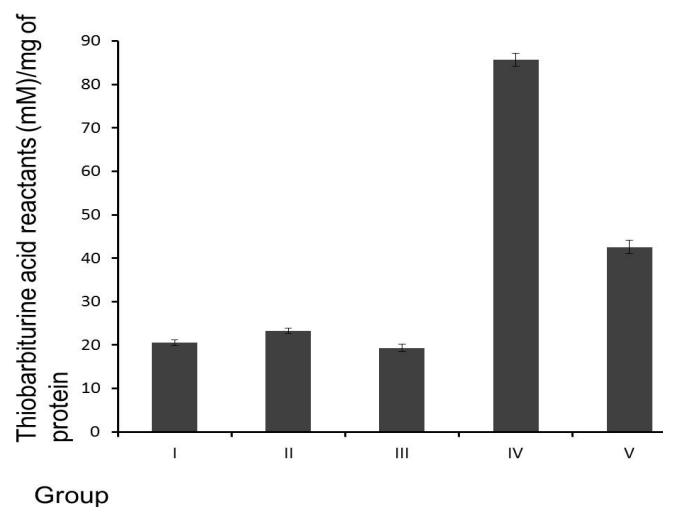

Figure 2: Effect of genistein on lipid peroxide levels in renal $I / R$ injury. The results are expressed as nanomoles of TBA reactants formed $/ \mathrm{mg}$ of protein. Group I (control); Group II (sham): Group III (genistein): Group IV (I/R): Group V (genistein + I/R). Results are given as the mean \pm SEM for 10 rats in each group; ${ }^{* * *} p<0.001$, when compared to control; ${ }_{\# \# \#} p<0.001$, when compared to I/R group; NS = not significant when compared to control

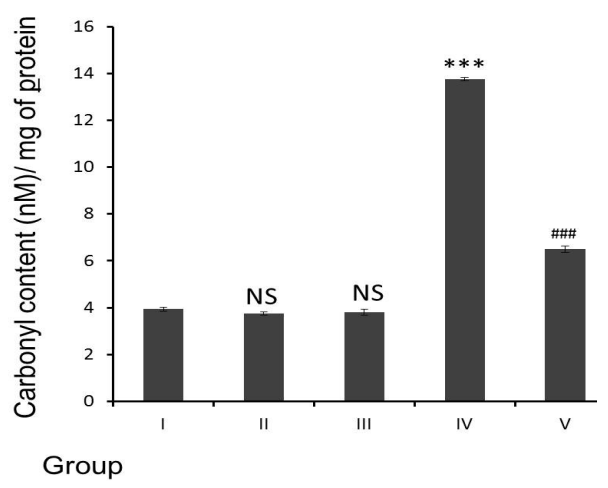

Figure 3: Effect of genistein on protein carbonyl content. The results are expressed as protein carbonyl content (nM)/mg of protein. Group I (control); Group II (sham): Group III (genistein): Group IV (I/R): Group V (genistein $+\mathrm{I} / \mathrm{R}$ ). Results are given as the mean \pm SEM for 10 rats in each group; ${ }^{* * *} p<0.001$, when compared to control; ${ }^{\# \#} p<0.001$, when compared to $\mathrm{I} / \mathrm{R}$ group; $\mathrm{NS}=$ not significant when compared to control

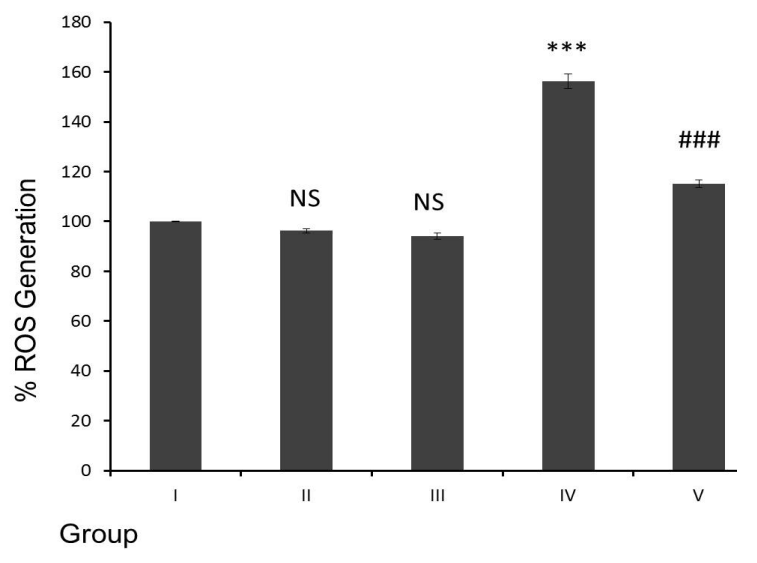

Figure 4: Effect of genistein on reactive oxygen species content in $\mathrm{I} / \mathrm{R}$ rats. The results are expressed as \% ROS generation compared to control (100\%). Group I (control); Group II (sham): Group III (genistein): Group IV (I/R): Group V (genistein + I/R). Results are given as the mean \pm SEM for 10 rats in each group. ${ }^{* * *} p<0.001$, when compared to control; $\# \#$ \# 0.001 , when compared to I/R group; NS = not significant when compared to control

\section{Genistein prevents renal I/R injury}

The levels of GSH found to be significantly decreased $(p<0.001)$ in I/R rats when compared to control group. Genistein treatment increased the GSH levels in a significant manner $(p<$ 0.001 ) when compared to $\mathrm{l} / \mathrm{R}$ alone treated rats (Table 2). The activities of enzymatic antioxidants (SOD, CAT, GST and GPx) were significantly declined when compared to control group. These antioxidant enzyme activities were significantly increased in rats treated with genistein followed by I/R injury. There was a nonsignificant difference in the antioxidant activities in sham rats and Genistein treated rats when compared to control group (Table 2).

Table 2: Effect of genistein on antioxidant status of rats with renal I/R injury

\begin{tabular}{|c|c|c|c|c|c|}
\hline Parameter & Group I & Group II & Group III & Group IV & Group V \\
\hline $\begin{array}{l}\mathrm{GSH}(\mathrm{nM} / \mathrm{mg} \\
\text { of protein) }\end{array}$ & $41.00 \pm 2.90$ & $41 \pm 1.98^{\mathrm{NS}}$ & $43.50 \pm 1.76^{\mathrm{NS}}$ & $19.00 \pm 2.51$ & $37.00 \pm 2.43^{\text {\#\# }}$ \\
\hline $\begin{array}{l}\text { SOD (U/mg } \\
\text { of protein) }\end{array}$ & $156.00 \pm 1.20$ & $154 \pm 2.13^{\mathrm{NS}}$ & $153.00 \pm 2.49^{\mathrm{NS}}$ & $128.00 \pm 2.08^{m \cdots}$ & $132.00 \pm 2.81^{\# \# \#}$ \\
\hline $\begin{array}{l}\mathrm{CAT}(\mathrm{U} / \mathrm{mg} \\
\text { of protein) }\end{array}$ & $1.44 \pm 0.01$ & $1.28 \pm 0.01^{\mathrm{NS}}$ & $1.41 \pm 0.02^{\mathrm{NS}}$ & $0.52 \pm 0.02^{* x}$ & $1.02 \pm 0.01^{\# \#}$ \\
\hline $\begin{array}{l}\mathrm{GPX}(\mathrm{U} / \mathrm{mg} \\
\text { of protein) }\end{array}$ & $2.32 \pm 0.01$ & $2.96 \pm 0.01^{\mathrm{NS}}$ & $2.41 \pm 0.02^{\mathrm{NS}}$ & $1.29 \pm 0.01$ & $1.62 \pm 0.01^{\# \# \#}$ \\
\hline GST (U/mg of & $36.00 \pm 1.23$ & $37.00 \pm 1.90^{\mathrm{NS}}$ & $35.00 \pm 1.56^{\mathrm{NS}}$ & $23.00 \pm 1.01{ }^{* *}$ & $31 \pm 1.65^{\mathrm{\# \#}}$ \\
\hline
\end{tabular}
protein)

Group I (control); Group II (sham): Group III (genistein): Group IV (I/R): Group V (genistein + I/R). Results are given as the mean \pm SEM $(n=10) ;{ }^{* *} p<0.001$, ${ }^{* *} p<0.01$ when compared to control. ${ }^{\# \#} p<0.05,{ }^{\# \# \#} p<0.001$, when compared to I/R group. NS = not significant when compared to control; GSH in nanomoles of GSH/mg of protein; SOD, CAT, GPX and GST activities in Units/mg protein 
A

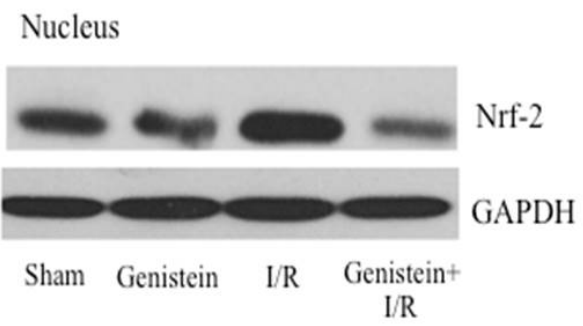

$\mathrm{C}$

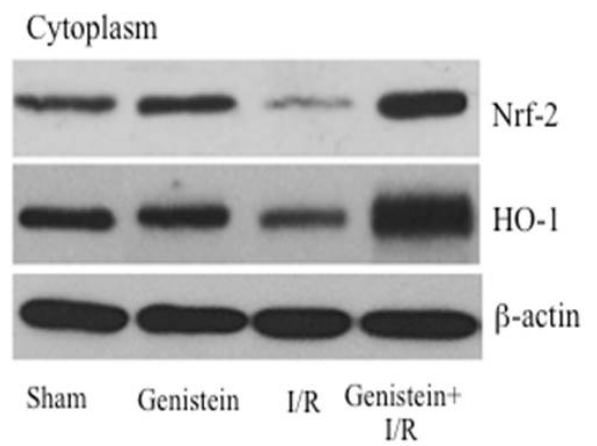

D
B
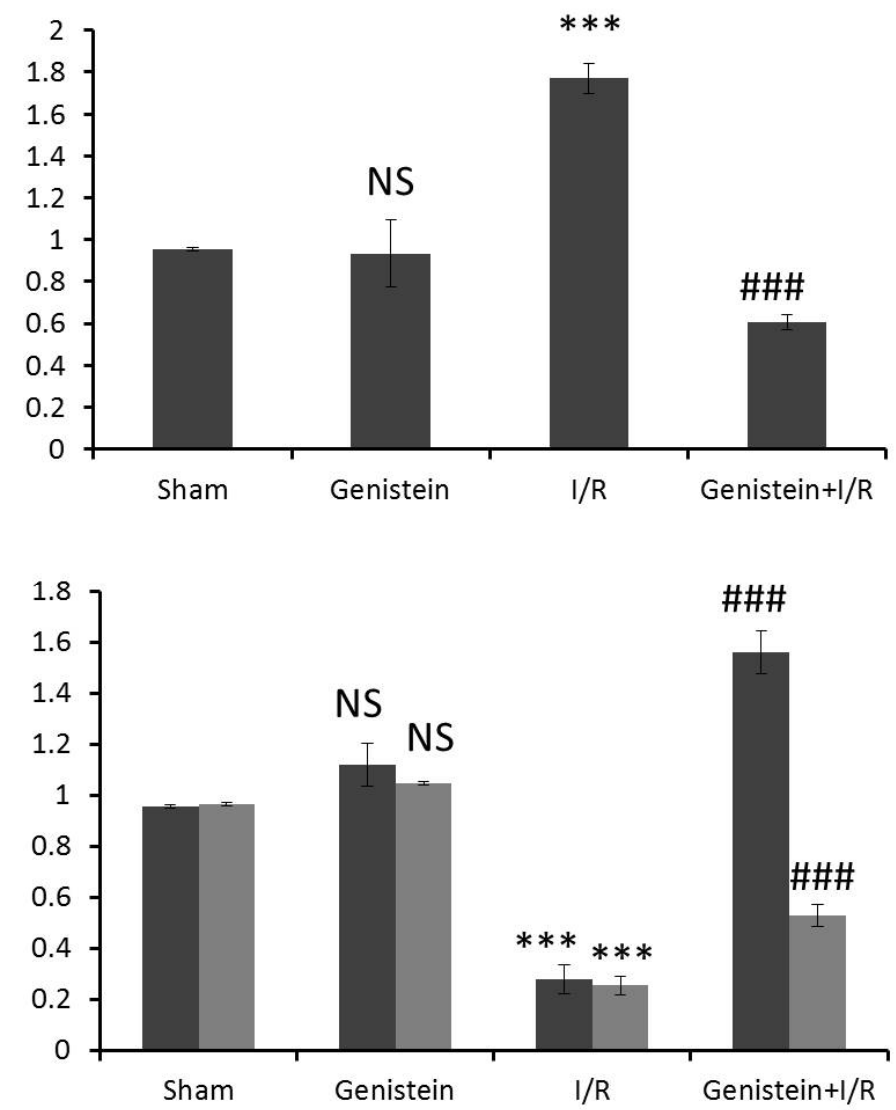

Figure 5: Genistein up regulates Nrf-2 and HO-1 expressions. A = nuclear expression of Nrf-2; GAPDH was used as internal control; $\mathrm{B}=$ Densitometric analysis of Nuclear Nrf-2 expression; $\mathrm{C}=$ Cytoplasmic expression of Nrf-2 and HO-1; D = Densitometric analysis of Nrf-2 and HO-1 expression; ${ }^{* \star *} p<0.001$, when compared to control; ${ }^{\# \#} p<0.001$, when compared to I/R group; NS = not significant when compared to control

\section{Genistein pre-treatment induces Nrf-2/HO-1 expression during I/R injury}

In order to determine whether protective effect of genistein is mediated by nrf-2 signaling we analyzed the expressions $\mathrm{Nrf}-2$ and $\mathrm{HO}-1$ in the wistar rats. Figure 5 shows that I/R injury caused significant decrease of Nrf-2 levels in the nucleus however treatment with genistein followed by $\mathrm{I} / \mathrm{R}$ injury increased nuclear Nrf-2 expressions. Further, HO-1 expression was significantly down regulated during $\mathrm{I} / \mathrm{R}$ injury, while pre-treatment with genistein increased the $\mathrm{HO}-1$ expressions compared to $\mathrm{I} / \mathrm{R}$ injury group.

\section{DISCUSSION}

The present study shows that genistein significantly offered cytoprotection against renal ischemic reperfusion injury in wistar rats. The increased level of serum markers (urea and creatinine) during $\mathrm{I} / \mathrm{R}$ injury demonstrates severe damage to the renal tissue. These levels were markedly reduced during genistein treatment in rats with $\mathrm{I} / \mathrm{R}$ injury. Further, genistein exerted protective effect by increasing the antioxidant capacity with concomitant decline in total oxidant status. Similar protective effect offered by genistein against renal damage by decreasing the serum urea and creatinine levels has been reported earlier [21].

Over production of ROS leads to oxidative stress conditions, which ultimately results in tissue injury. One of the most sensitive organs for oxidative stress includes kidney and the present study showed a significant increase in the levels of reactive oxygen species during renal $\mathrm{l} / \mathrm{R}$ injury. Intracellular reactive oxygen species include species such as hydrogen peroxide $\left(\mathrm{H}_{2} \mathrm{O}_{2}\right)$, hypochlorous acid $(\mathrm{HClO})$, superoxide anion $\left(\mathrm{O}^{-}\right.$ ). Any imbalance in these levels leads to rise in ROS levels, which results in damage to DNA, lipid and proteins. Reactive species interact with unsaturated bonds in lipid moieties and leads to the formation of lipid peroxides [22]. These species also result in oxidation of proteins and ultimately results in the formation of protein carbonyls. The stable moieties are measured biochemically, which acts as an important biomarker in protein damage [23]. The present studies showed a significant increase in lipid 
peroxide levels and protein carbonyl content during $\mathrm{I} / \mathrm{R}$ injury. A significant accumulation of MDA and protein carbonyls during $\mathrm{l} / \mathrm{R}$ injury was ameliorated during genistein treatment. Additionally, Genistein treatment during ischemic reperfusion injury reduced reactive oxygen species generation, thus it might be the reason for its preventive effects against various downstream events against $I / R$ induced oxidative stress. The antioxidant property of genistein against the amelioration oxidative stress status through inhibition of lipid peroxidation and ROS generation has been documented earlier [24].

It has been well documented that antioxidant defense mechanisms play a crucial role in protecting against various diseased conditions, which is primarily mediated through oxidative stress. Various phase II cytoprotective enzymes such as SOD, CAT, GST and GPx are involved in protective role. GSH is an important nonprotein thiol, which is endogenous in nature, acts as a first defense against oxidative stress conditions [25]. Enzymatic antioxidants act in coherence in the efficient removal of toxic species from the cell. Superoxide dismutase reacts with superoxides and results in the formation of hydroxyl radicals. Catalase reacts with the hydroxyl radicals and forms $\mathrm{H}_{2} \mathrm{O}$ and $\mathrm{O}_{2}$ [26]. GSH in conjugation with GPx offers protection from various toxic metabolites [27]. The present study shows that I/R injury lead to decrease in levels of GSH content and enzymatic antioxidants (superoxide dismutase, catalase, glutathione peroxidase and glutathione-Stransferase). However, genistein treatment followed by $\mathrm{I} / \mathrm{R}$ injury showed a significant increase in both enzymatic and non-enzymatic antioxidant status. Further, we also demonstrate here that Genistein induced protection against $\mathrm{l} / \mathrm{R}$ injury was mediated through $\mathrm{Nrf}-2 / \mathrm{HO}-1$ signaling mechanisms. Nrf-2 (nuclear factor erythroid 2-related factor 2) is a nuclear transcription factor and well established as oxidative stress regulator. Under normal and oxidative stress conditions, Nrf-2 controls the antioxidant defense mechanisms. Nrf-2 translocates into nucleus and binds to antioxidant response elements (ARE)- and induces expression of HO-1, GCL, NQO1 [28]. Genistein induced improved antioxidant enzyme activities have been reported earlier and the mechanism of protection has been linked with up-regulation of Nrf-2 activation and expression [29].

\section{CONCLUSION}

The findings of the present study show clear evidence that genistein treatment offers significant protective effect against renal ischemic reperfusion injury in rats by reducing renal damage and oxidative stress with concomitant increase in antioxdative defense mechanisms. Thus, nutritional intervention with genistein may be a promising strategy against ischemic reperfusion injury.

\section{DECLARATIONS}

\section{Conflict of Interest}

No conflict of interest associated with this work.

\section{Contribution of Authors}

The authors declare that this work was done by the authors named in this article and all liabilities pertaining to claims relating to the content of this article will be borne by them.

\section{Open Access}

This is an Open Access article that uses a funding model which does not charge readers or their institutions for access and distributed under the terms of the Creative Commons Attribution License (http://creativecommons.org/licenses/by 14.0) and the Budapest Open Access Initiative (http://www.budapestopenaccessinitiative.org/rea d), which permit unrestricted use, distribution, and reproduction in any medium, provided the original work is properly credited.

\section{REFERENCES}

1. Xue JL, Daniels F, Star RA, Kimmel PL, Eggers PW, Molitoris BA, Himmelfarb $J$, Collins AJ. Incidence and mortality of acute renal failure in Medicare beneficiaries, 1992 to 2001. J Am Soc Nephrol 2006; 17: 1135-1142.

2. Chen HH, Sundt TM, Cook DJ, Heublein DM, Burnett JC Jr. Low dose nesiritide and the preservation of renal function in patients with renal dysfunction undergoing cardiopulmonary-bypass surgery: a double-blind placebo-controlled pilot study. Circulation 2007; 116: /134-/1138.

3. McCord JM. Oxygen-derived free radicals in postischemic tissue injury. N Engl J Med 1985; 312: 159-163.

4. Carden DL, Granger DN. Pathophysiology of ischaemiareperfusion injury. J Pathol 2000; 190: 255-266.

5. Sirin BH, Ortac $R$, Cerrahoglu $M$, Saribulbul O, Baltalarli A, Celebisoy N, Iskesen I, Rendeci O. Ischaemic preconditioning reduces spinal cord injury in transient ischaemia. Acta Cardiol 2002; 57: 279-285.

6. Park CE, Yun H, Lee EB, Min BI, Bae H, Choe W, Kang I, $\mathrm{Kim}$ SS, Ha J. The antioxidant effects of genistein are associated with AMP-activated protein kinase activation 
and PTEN induction in prostate cancer cells. J Med Food 2010; 13: 815-820.

7. Belevych $A E$, Warrier S, Harvey RD. Genistein inhibits cardiac l-type $\mathrm{Ca}^{2+}$ channel activity by a tyrosine kinaseindependent mechanism. Mol. Pharmacol. 2002; 62: 554-565.

8. National Research Council (NRC), "Guide for the Care and Use of Laboratory Animals": 8th Ed., in: Guide for the Care and Use of Laboratory Animals. National Research Council 2011; p 118.

9. Natelson S, Scott ML, Vessac N. Rapid method for the estimation of urea in biological fluid by means of reaction between diacetyl and urea. Am. J. Clin. Pathol. 1951; 21: 275-278.

10. Broad J, Sirota JH. Clearance of endogenous creatine in man. J. Clin. Investig. 1948; 27: 645-654.

11. Erel O. Novel automated method to measure total antioxidant response against potent free radical reactions. Clin. Biochem. 2004; 37: 112-119.

12. Erel O. A new automated colorimetric method for measuring total oxidant status. Clin. Biochem. 2005; 38 : 1103-1111.

13. Lowry $\mathrm{OH}$, Rosenbrough NJ, Farr AL, Randall RJ. Protein measurement with the Folin phenol reagent. $J$. Biol. Chem. 1951; 193: 265-275.

14. Hashimoto M, Tanabe $Y$, Fujii $Y$, Kikuta $T$, Shibata $H$, Shido O. Chronic administration of docosahexaenoic acid ameliorates the impairment of spatial cognition learning ability in amyloid betainfused rats. J. Nutr. 2005; 135: 549-555.

15. Levine R, Garland D, Oliver C. Determination of carbonyl content of oxidatively modified proteins. Methods. Enzymal. 1990; 186: 464-464.

16. Ohkawa H, Ohishi N, Yagi K. Assay for lipid peroxides in animal tissues by thiobarbituric acid reaction. Anal. Biochem. 1979; 95: 351-358.

17. Sun Y, Oberley LW, Ying L. A simple method for clinical assay of superoxide dismutase. Clin. Chem. 1998; 34 : 497-500.
18. Habig WH, Pabst MJ, Jakoby WB. Glutathione Stransferases. The first enzymatic step in mercapturic acid formation. J. Biol. Chem. 1974; 249: 7130-7139.

19. Paglia DE, Valentine WN. Studies on the quantitative and qualitative characterisation of erythrocyte glutathione peroxidase. J. Lab. Clin. Med. 1967; 70: 158-169.

20. Aebi H. Catalase In: Bergmeyer $U$ (ed) Methods of enzymatic analysis. Academic Press, New York, 1974; p. 673-684.

21. Kim MJ, Lim Y. Protective Effect of Short-Term Genistein Supplementation on the Early Stage in DiabetesInduced Renal Damage. Mediators Inflamm. 2013; 1-14.

22. Ikeda $Y$, Long DM. The molecular basis of brain injury and brain edema the role of oxygen free radicals. Neurosurgery. 1990; 27: 1-11.

23. Berlett $B$, Stadtman ER. Protein oxidation in aging, disease, and oxidative stress. J. Biol. Chem. 1997; 272: 20313- 6 .

24. Ferretti G, Bacchetti T, Menanno F, Curatola G. Effect of genistein against copper-induced lipid peroxidation of human high density lipoproteins (HDL). Atherosclerosis. 2004; 172:55-61.

25. Reed DJ. Glutathione: toxicological implications. Annu. Rev. Pharmacol. Toxicol. 1990; 30: 603-631.

26. Burton GW, Cheesman HN, Ingold KV, Seater TF. Lipid antioxidants and products of lipid peroxidation as potential tumor protective agents. Biochem. Soc. Trans. 1983; 11: 261-262.

27. Micheiels $C$, Raes $M$, Toussaint $O$, Remach J. Importance of Se-glutathione, catalase, and Cu/Zn superoxide dismutase for cell survival against oxidative stress. Free. Radic. Biol. Med. 1994; 17: 235-248.

28. Müller T, Hengstermann A. Nrf2: friend and foe in preventing cigarette smoking-dependent lung disease. Chem. Res. Toxicol. 2012; 25: 1805-1824.

29. Zhang T, Wang F, Xu HX, Yi L, Qin Y, Chang H, Mi MT, Zhang QY. Activation of nuclear factor erythroid 2related factor 2 and PPARY, plays a role in the genistein-mediated attenuation of oxidative stressinduced endothelial cell injury. Br. J. Nutr. 2013; 109: 223-235. 